\title{
Effects of the 'Amoco Cadiz' Oil Spill on the Seagrass Community at Roscoff with Special Reference to the Benthic Infauna
}

\author{
R. P. W. M. Jacobs \\ Laboratory of Aquatic Ecology, Catholic University, Toernooiveld, 6525 ED Nijmegen, The Netherlands
}

\begin{abstract}
The benthic fauna of an eelgrass (Zostera marina L.) community has been investigated at Roscoff (France) from October 1977 to April 1979. The impact of the 'Amoco Cadiz' oil spill of March 1978 on the community was studied. Direct effects on the eelgrass itself were only local during the first weeks after the spill, when many plants had black, 'burnt' leaves. This was, however, a temporary phenomenon, for the production of new leaf tissue continued normally. Effects on the benthic fauna were observed directly after the arrival of the oil at Roscoff. A sharp decrease in numbers of both individuals and species occurred mainly caused by an almost total disappearance of the smaller Crustacea and Echinodermata, and a serious numerical decrease in other groups. Recovery took place relatively rapidly. In the beginning of 1979 all numbers were at the same level as the year before, the filter feeding Amphipoda being the only exception: on 1 May 1979 they were still absent.
\end{abstract}

\section{INTRODUCTION}

In the night of 16 March 1978 the tanker 'Amoco Cadiz' went aground on the rocks near Portsall at the northwestern point of the coast of Brittany (France). In the course of the next $15 \mathrm{~d}$ the cargo of $216,000 \mathrm{t}$ of crude oil and 4,000 $\mathrm{t}$ of bunker fuel were released into the ocean and caused severe pollution as far as Ile de Bréhat (Bay of St. Brieuc).

After the spill, investigators of a variety of scientific disciplines participated in the study of the physical, chemical and biological effects of the pollution and the first reports were published after some months (Conan et al., 1978; Hess, 1978).

The 'Amoco Cadiz' spill brought on radical changes in an ecological study of structural and functional aspects of seagrass communities by the Laboratory of Aquatic Ecology in Nijmegen (The Netherlands). This investigation started in 1976 at Roscoff with a study of the production and biomass of eelgrass Zostera marina L. (Jacobs, 1979), and was followed in October 1977 by an investigation of the composition of the fauna of the seagrass community. Since March 1978 the sampling program has been continued in order to elucidate the impact of oil on the fauna. Although the collected data have not yet been completely analysed, a first survey of the results is presented here, and effects of the spill on the seagrass community are discussed.

\section{STUDY AREA}

At Roscoff, the eelgrass Zostera marina constitutes the basis of the seagrass community and forms dense beds, which are distributed from mean low water neap level (MLWN) down to a depth of $4 \mathrm{~m}$ below mean low water spring level (MLWS). In these meadows a relationship exists between the above-ground plant biomass, length of leaves, number of shoots $\mathrm{m}^{-2}$ and water coverage, i.e. the percentage of time each contour is covered with water. The below-ground plant parts form a dense mat of interwoven rhizomes and roots, the thickness of which is determined by the age of the bed and the sedimentation rate. For more details concerning distribution, biomass and production of $Z$. marina, see Jacobs (1979).

Apart from the seagrass itself, a number of other structural elements can be recognized in the community (den Hartog, 1979), e.g. (1) epiphytic algae on the seagrass; (2) a mat of loose-lying algae, caught by the seagrass; (3) vagile fauna on the seagrass; (4) sessile fauna on the bottom surface; (5) vagile fauna on the bottom surface; (6) benthic infauna.

On 20 March 1978 the first oil reached Roscoff and remained well visible during the following weeks. Only thickness and extent of the oil slick varied from day to day. During low-water periods oil covered the eelgrass beds but, at high tide, vertical transport pro- 
cesses always resulted in a loosening of the direct contact, because the beds are situated below MLWN. During April and May the impact on the eelgrass was distinct: especially at the boundaries of the beds in the higher littoral, some leaves were black and looked burnt, in others transparent parts were visible. Later these leaves were shed; however, the plants were not dead: even production continued normally.

For the study of the fauna of the eelgrass community 2 homogeneous beds were chosen: one just below MLWN level and the other approximately $0.5 \mathrm{~m}$ lower. The eelgrass bed situated in the higher littoral (just below MLWN) was characterized by a large number of shoots $\left(700-800 \mathrm{~m}^{-2}\right)$, which were, however, short $(<$ $30 \mathrm{~cm})$. There was no mat of loose-lying algae. The rhizome mat was approximately $9 \mathrm{~cm}$ thick. This eelgrass bed fell dry at almost each low water period. In the lower Zostera marina bed there were fewer shoots $\left(500-600 \mathrm{~m}^{-2}\right)$, but they were longer (up to $50 \mathrm{~cm}$ ); the thickness of the rhizome mat was approximately $6 \mathrm{~cm}$. This bed was situated in an enormous tidal pool, that retained a water level of some centimetres at each low tide. Between the shoots, a mat of loose-lying algae was present; locally this mat was several centimetres thick. The mat was mainly composed of Corallina officinalis L., Cladostephus spongiosus (Huds.) C. Ag. and Sphacelaria species.

From October 1977 to April 1979 in both eelgrass beds a bottom sample of $20 \times 20 \mathrm{~cm}$ was taken monthly in order to study the fauna. In the laboratory these samples were sieved ( $1 \mathrm{~mm}$ mesh size) and all individuals were collected and preserved. After identification to species, each sample was characterized by 4 parameters: number of individuals $(\mathrm{N})$, number of species $(\mathrm{S})$, calculated species diversity $(\mathrm{H})$ and evenness (J) (Pielou, 1969).

Since most diversity measurements are affected by sample size, the latter was kept constant in order to be able to compare samples taken in different seasons. However, spatial distribution of the component species affects the diversity patterns. Comparison of 4 samples of $20 \times 20 \mathrm{~cm}$, taken simultaneously, showed a random or aggregated distribution of the individuals over the samples for $99 \%$ of all species. The number of species per sample was approximately $65 \%$ of the total number of species present.

\section{RESULTS}

The fauna in the upper eelgrass bed showed a decrease in both total numbers of individuals and numbers of species at the end of 1977 (Fig. 1). This has to be regarded as a normal fluctuation of the fauna of an eelgrass bed at the upper limit of its occurrence (i.e.

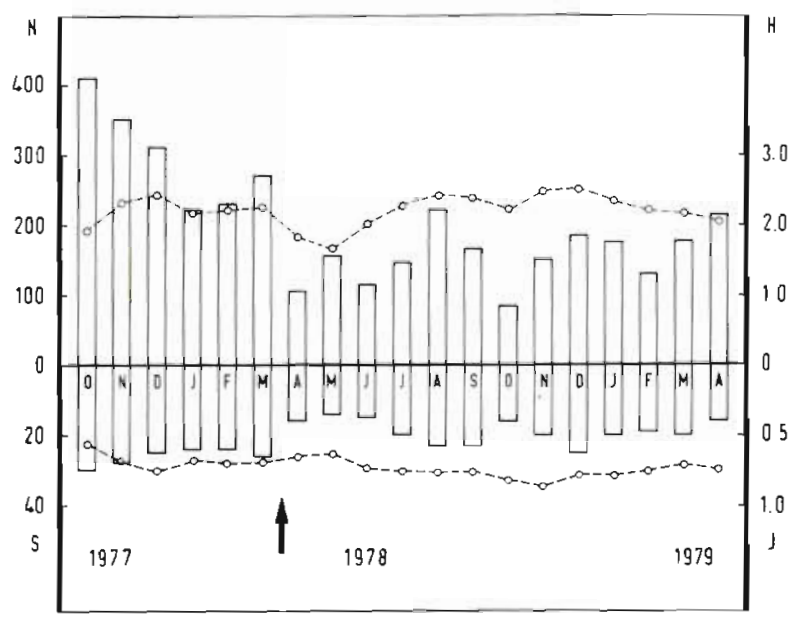

Fig. 1. Characteristics of the fauna of the upper Zostera marina bed at Roscoff (just below MLWN level), October 1977 to April 1979. Total numbers $400 \mathrm{~cm}^{-2}$ of individuals (N) and species $(\mathrm{S})_{\text {; }}$ calculated diversity index $(\mathrm{H})$ and evenness $(\mathrm{J})$ given as broken lines. Arrow: moment of oil arrival at Roscoff

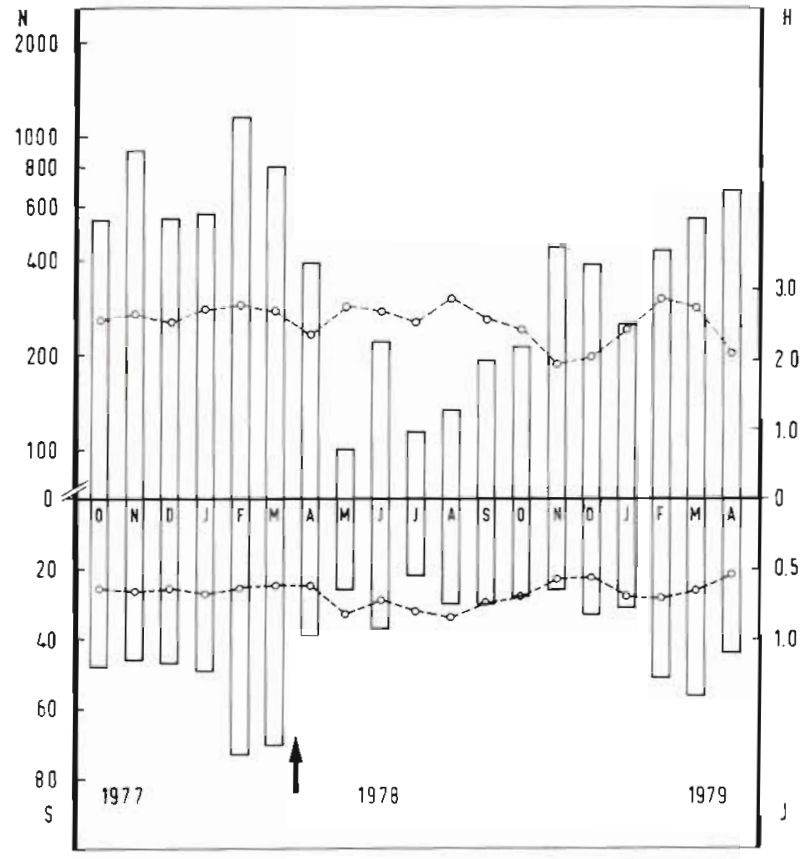

Fig. 2. Characteristics of the fauna of the lower Zostera marina bed at Roscoff (approximately $0.5 \mathrm{~m}$ below MLWN level), October 1977 to April 1979. Total numbers $400 \mathrm{~cm}^{-2}$ of individuals $(\mathrm{N})$ and species $(\mathrm{S})$; calculated diversity index $(\mathrm{H})$ and evenness ( $\mathrm{J}$ ) given as broken lines. Arrow: moment of oil arrival at Roscoff

at MLWN). At this level the bed is exposed to increased sedimentation, which results in the deposition of a sand layer several centimetres thick between shoots. Eventually this leads to a thickening of the rhizome mat and a raising of the bed. These changes are normal stages in the development of the community (Blois et al., 1961; den Hartog, 1973). 


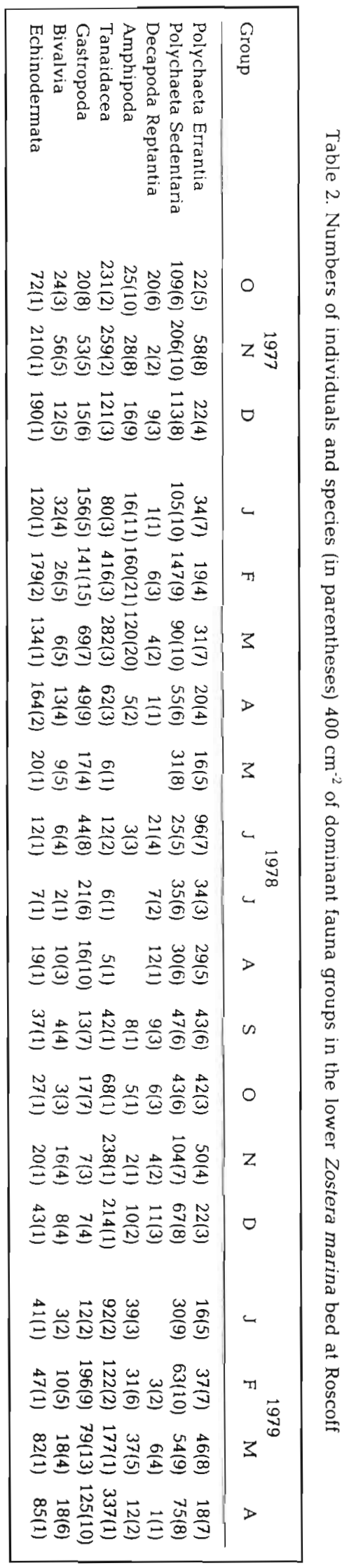

\begin{tabular}{|c|c|}
\hline 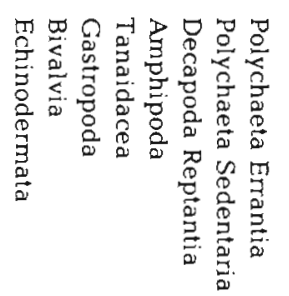 & $\begin{array}{l}8 \\
8 \\
8\end{array}$ \\
\hline 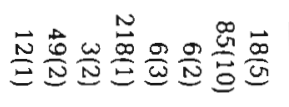 & 0 \\
\hline 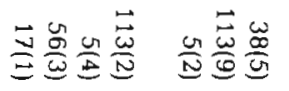 & $z \stackrel{\vec{g}}{y}$ \\
\hline 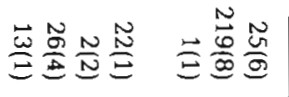 & $\theta$ \\
\hline 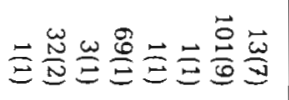 & $\omega$ \\
\hline 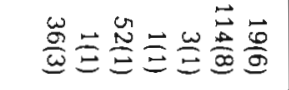 & $\pi$ \\
\hline 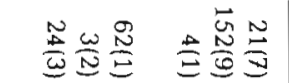 & 3 \\
\hline 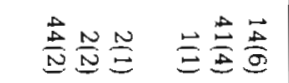 & $>$ \\
\hline 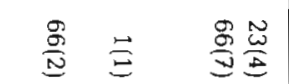 & 3 \\
\hline 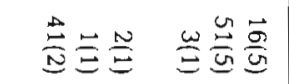 & $\omega$ \\
\hline 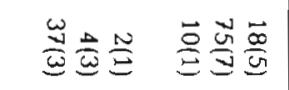 & $-\infty$ \\
\hline 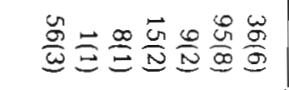 & $>$ \\
\hline 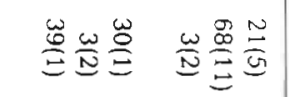 & es \\
\hline 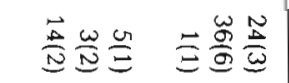 & 0 \\
\hline$\stackrel{\omega}{N} \frac{D}{N} \stackrel{M}{\Xi} \stackrel{\vec{N}}{\vec{E}} \frac{N}{\omega}$ & $z$ \\
\hline 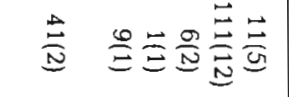 & $\sigma$ \\
\hline$\stackrel{\vec{N}}{\Xi} \stackrel{\overrightarrow{0}}{\Xi}$ 㤩兽苛 & - \\
\hline 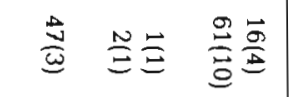 & $\overrightarrow{0}$ \\
\hline 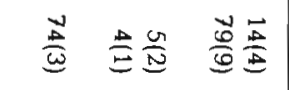 & $3^{0}$ \\
\hline$\stackrel{\vec{N}}{\stackrel{\tilde{O}}{\Xi}} \vec{\Xi} \overrightarrow{\frac{B}{0}} \frac{\vec{N}}{\omega}$ & $D$ \\
\hline
\end{tabular}


The first samples after the 'Amoco Cadiz' oil spill showed a numerical decrease in species. Further, only half of the numbers of individuals present before the spill were found. This resulted in a decrease of the diversity index from 2.26 in March 1978 to 1.66 in May 1978 (Fig. 1). After May the diversity recovered within 3 months due to an increasingly proportional distribution of the individuals over the species found in the samples. The numbers of individuals and species increased somewhat but remained fluctuating slightly during further observation in 1978 and 1979. The values from the end of 1977 were never reached again due to the raising of this bed as described above. However, the relatively high and rather stable values of diversity during the second half of the investigation period (Fig. 1) indicate a stable community with high diversity.

After the spill, the polychaetes comprised the most abundant group of the fauna (Table 1). The best represented were, in order of relative abundance, the Maldanidae ( 2 species), the Capitellidae ( 3 species) and the Spionidae (4 species). The bivalve Loripes lacteus (L.) was also represented by numerous individuals. Representatives of the 3 polychaete families were abundant before the spill, but the Spionidae recovered apparently less quickly than the Capitellidae and Maldanidae (Table 3).

In the lower eelgrass bed, more individuals, as well as species of macrofauna, were found than in the upper littoral bed during the investigation period. This difference was most distinct before the oil spill and again from November 1978 (Fig. 2). It was only in May 1978 that the impact of the oil spill on the benthic fauna was perceptible in a prominent decrease in the numbers of individuals and species. This was mainly caused by the virtual disappearance of Amphipoda, Tanaidacea and Echinodermata; the numbers of Gastropoda, Polychaeta Sedentaria and Bivalvia also decreased (Table 2).

The sample taken in Juni 1978 contained more species and individuals, mainly herbivorous species, due to an algal bloom. At that time the littoral was covered with enormous quantities of UIva lactuca L., Enteromorpha spp. and Ceramium rubrum (Huds.) C. Ag., while the eelgrass was covered with the epiphyte Ectocarpus sp.

Various stimulating factors can be pointed out as causes for this exceptional growth, which were probably effective in combination: (1) a possibly stimulating effect of some oil components in low concentrations; (2) increase in nutrients released from oil-killed organisms; (3) reduced population size of herbivorous Gastropoda; (4) normal increase of water temperature and irradiance after the winter.

The recovery of the fauna of the lower eelgrass bed proceeded very quickly: at the end of 1978 the total numbers of individuals and species were at the same level as the year before, although fluctuations in diversity values indicated a certain degree of instability of the community due to fluctuations in the numbers of the dominant species (Fig. 2). The Echinodermata recovered slowly; the only exception in the whole process were the Amphipoda (Table 2), among which the filter feeders did not return.

Polychaeta Sedentaria were the dominant benthic infauna group during the whole investigation period. Capitellidae (2 species) were the most abundant, followed by Spionidae (5 species), Maldanidae (2 species), Sabellidae ( 4 species) and Terebellidae ( 4 species). Representatives of all 5 families were affected by the oil; Capitellidae recovered very quickly, Spionidae

Table 3. Numbers of representatives $400 \mathrm{~cm}^{-2}$ of the most important families of the Polychaeta Sedentaria in the two investigated Zostera marina beds at Roscoff

\begin{tabular}{|c|c|c|c|c|c|c|c|c|c|c|c|c|c|c|c|c|c|c|c|}
\hline \multirow[b]{2}{*}{ Group } & \multicolumn{3}{|c|}{1977} & \multirow[b]{2}{*}{$\mathrm{J}$} & \multirow[b]{2}{*}{$F$} & \multirow[b]{2}{*}{$M$} & \multirow[b]{2}{*}{ A } & \multicolumn{4}{|c|}{1978} & \multirow[b]{2}{*}{$\mathrm{S}$} & \multirow[b]{2}{*}{0} & \multirow[b]{2}{*}{$N$} & \multirow[b]{2}{*}{ D } & \multicolumn{4}{|c|}{1979} \\
\hline & $\mathrm{O}$ & $N$ & $\mathrm{D}$ & & & & & M & $\mathrm{J}$ & $\mathrm{J}$ & A & & & & & $\mathrm{J}$ & $\mathrm{F}$ & $M$ & A \\
\hline \multicolumn{20}{|c|}{ Eelgrass bed, high in the littoral } \\
\hline Spionidae & 30 & 30 & 49 & 40 & 24 & 32 & 1 & 6 & 12 & 22 & 37 & 22 & 8 & 24 & 39 & 23 & 15 & 21 & 33 \\
\hline Capitellidae & 33 & 51 & 119 & 35 & 35 & 67 & 24 & 16 & 23 & 26 & 26 & 25 & 20 & 15 & 26 & 25 & 21 & 29 & 34 \\
\hline Maldanidae & 19 & 29 & 49 & 32 & 51 & 48 & 14 & 42 & 15 & 26 & 39 & 14 & 2 & 28 & 36 & 29 & 21 & 22 & 40 \\
\hline Terebellidae & 1 & 1 & 2 & 3 & & 4 & & 1 & & & 2 & 1 & & 1 & 2 & 1 & & 1 & 1 \\
\hline Sabellidae & 1 & & & & & & & & & & 1 & 1 & & & & & & & \\
\hline \multicolumn{20}{|c|}{ Eelgrass bed, low in the littoral } \\
\hline Spionidae & 9 & 43 & 18 & 17 & 52 & 14 & 5 & 3 & 6 & 6 & 11 & 18 & 21 & 49 & 17 & 6 & 14 & 14 & 6 \\
\hline Capitellidae & 39 & 75 & 71 & 47 & 43 & 34 & 32 & 19 & 4 & 26 & 11 & 13 & 15 & 41 & 33 & 17 & 40 & 26 & 37 \\
\hline Maldanidae & 7 & 77 & 15 & 18 & 39 & 27 & 9 & 1 & 14 & 1 & 7 & 5 & 6 & 12 & 9 & 2 & 1 & 7 & 29 \\
\hline Terebellidae & 2 & 8 & 1 & 6 & 6 & 6 & 1 & 3 & 1 & 1 & 1 & & 1 & 1 & 4 & & 3 & 1 & \\
\hline Sabellidae & 52 & 3 & 8 & 15 & 7 & 8 & 8 & 2 & & & & 1 & & 1 & 4 & 4 & 5 & 5 & 1 \\
\hline
\end{tabular}


followed later, whereas in the winter of 1978/79 Maldanidae, Terebellidae and Sabellidae were still found in somewhat lower numbers than in the year before (Table 3).

\section{DISCUSSION}

Eelgrass without visible damage contained - on 31 March 1978 at Portsall - hydrocarbons originating from the 'Amoco Cadiz' oil (Calder et al., 1978). It is unknown whether hydrocarbon uptake was an active process, as shown for phosphorus (McRoy et al., 1972) and carbon (Wetzel and Penhale, 1979). However, by this uptake Zostera marina has played an important part in the fixation of oil components. Taking into account a mean production rate for eelgrass leaves of one every $19 \mathrm{~d}$ and a turnover time for the aboveground plant parts of $68 \mathrm{~d}$ (Jacobs, 1979), a considerable fixation of oil components could take place in a short time. The fact that these plant parts were quickly washed away may have reduced the amount of oil in the vulnerable littoral communities.

The situation of the eelgrass beds (below MLWN) implied a direct contact of the oil slick with the beds for a maximum of $6 \mathrm{~h}$ a day. During this time the prostrate eelgrass leaves prevented direct contact of the oil with the bottom. In addition, mechanical mixing of oil with sediment was impossible by the thick rhizome mat, so that only the dissolved fraction could penetrate into the interstitial water. This may explain how mainly filter feeders were affected, e.g. Amphipoda and Sabellidae, and how the numbers of Terebellidae, indirect deposit feeders living just above the bottom surface in the mat of algae, were also diminished. On the other hand, direct deposit feeders living in the bottom, e.g. Maldanidae and Capitellidae, showed rapid recovery. Spionidae, which are transitional between indirect deposit feeders and filter feeders, also recovered rather quickly

Some months after the spill an exceptional growth of green algae was observed at some places (Marchand et al., 1979), but there was no universal 'greening' as after the 'Torrey Canyon' spill (Southward and Southward, 1978). This may be due to the almost complete persistence of cover by macroalgae, and to the lesser and locally very different mortality of herbivorous gastropods (Chassé, 1978b).

The algal bloom at Roscoff in June concerned a normal annual phenomenon, concurring with an increase of available nutrients after the winter period and of temperature and irradiance in spring (Grall and Jacques, 1964). However, the extent of the bloom in 1978 was greater than in preceding years, suggesting stimulating effects of oil components (Gesamp, 1977) and/or an increase in nutrients released from oil-killed organisms. The bloom was directly followed by recolonization of herbivores, and within a short time (a few months) the situation had returned to 'normal'.

However, this short algal bloom is a sign of imbalance in the ecosystem. Such instability is also observed in the eelgrass community, reflected by fluctuations in the diversity indices of benthic fauna populations. For the upper littoral Zostera marina bed, these fluctuations show changes imposed not only by oil pollution, but also by processes inherent to dynamics of the community at this level, e.g. raising of this bed. However, before the spill the lower eelgrass bed was a highly diverse community (see values for $\mathrm{S}, \mathrm{N}, \mathrm{H}$ and $\mathrm{J}$ in Fig. 1,2). After the perturbation the numbers of species and individuals decreased rapidly and recovered within one year, but the fluctuating diversity values are characteristic of the instability of the community structure with a sequence of 'dominants'. Theoretically this can be caused by non-simultaneous reproduction activities of the different species. However, this is contradicted by diversity values of corresponding months before and after the spill.

Lack of data on the influence of 'Amoco Cadiz' oil on other littoral communities makes comparison very difficult. Taking into account the numbers of dead organisms reported from other intertidal communities (Chassé, 1978a; Hyland, 1978), it can be concluded that the Zostera marina beds formed a sheltered habitat for numerous species: effects of the 'Amoco Cadiz' oil spill have been observed, but - with the exception of the Amphipoda - the benthic fauna of the community recovered within one year and only shortterm effects could be detected on the eelgrass itself.

Acknowledgements. I would like to thank J. Stassen, W. Huisman, W. Buys, L. Pierson, N. Manders and T. de Jong for providing practical assistance throughout this study. I am also indebted to Professor Dr. C. den Hartog and Drs. J. T. A. Verhoeven for critically reviewing the manuscript, and to Mr. J. J. A. Slippens for the drawings. A great part of the practical work was carried out at the Station Biologique at Roscoff; I thank the director, Professor Dr. J. Bergerard and his staff for hospitality. The first part of this investigation (to April 1978) was made possible by financial support from the Netherlands Organization for the Advancement of Pure Research (ZWO), the second part was financed by the Shell Internationale Research Maatschappij.

\section{LITERATURE CITED}

Blois, J. C., Francaz, J. M., Gaudichon, M., Gaudichon, S., Le Bris, L. (1961). Observations sur les herbiers à Zostères de la région de Roscoff. Cah. Biol. mar. 2: 223-262

Calder, J. A., Lake, J., Laseter, J. (1978). Chemical composition of selected environmental and petroleum samples from the Amoco Cadiz oil spill. In: Hess, W. N. (ed.) The 
Amoco Cadiz oil spill. A preliminary scientific report. NOAA/EPA Special Report, US Government Printing Office, Washington, pp. 21-82

Chassé, C. (1978a). Esquisse d'un bilan écologique provisoire de l'impact de la marée noire de l"Amoco Cadiz' sur le littoral. In: Conan, G, d'Ozouville, L., Marchand, M. (eds) Amoco Cadiz. Premières observations sur la pollution par les hydrocarbures. Publications du Centre National pour l'Exploitation des Océans (CNEXO), Actes de Colloques, 6. Brest, France, pp. 115-134

Chassé, C. (1978b). The ecological impact on and near shores by the Amoco Cadiz oil spill. Mar. Pollut. Bull. 9: 298-301

Conan, G., d'Ozouville, L., Marchand, M. (eds) (1978). Amoco Cadiz. Premières observations sur la pollution par les hydrocarbures. Publications du Centre National pour l'Exploitation des Océans (CNEXO), Actes de Colloques, 6. Brest, France

den Hartog, C. (1973). The dynamic aspect in the ecology of seagrass communities. Thalassia jugosl. 7 : 101-112

den Hartog, C. (1979). Seagrasses and seagrass ecosystems, an appraisal of the reasearch approach. Aquat. Bot. 7 : 105-117

GESAMP (IMCO/FAO/UNESCO/WMO/WHO/IAEA/UN Joint Group of Experts on the Scientific Aspects of Marine Pollution) (1977). Impact of oil on the marine environment. Rep. Stud. GESAMP 6: 1-250

Grall, J.-R., Jacques, G. (1964). Etude dynamique et variations saisonnières du plancton de la région de Roscoff $I$. Cah. Biol. mar. 5: 423-455

Hess, W. N. (ed.) (1978). The Amoco Cadiz oil spill. A prelimi- nary scientific report. NOAA/EPA Special Report. US Government Printing Office, Washington

Hyland, J. L. (1978). Onshore survey of macrobenthos along the Brittany coast following the Amoco Cadiz oil spill. In: Conan, G., d'Ozouville, L., Marchand, M. (eds) Amoco Cadiz. Premières observations sur la pollution par les hydrocarbures. Publications du Centre National pour l'Exploitation des Océans (CNEXO), Actes de Colloques, 6. Brest, France, pp. 175-192

Jacobs, R. P. W. M. (1979). Distribution and aspects of the production and biomass of eelgrass, Zostera marina L., at Roscoff, France. Aquat. Bot. 7: 151-172

Marchand, M., Conan, G., d'Ozouville, L. (1979). Bilan écologique de la pollution de l'Amoco Cadiz. Publications du Centre National pour l'Exploitation des Océans (CNEXO), Rapports Scientifiques et Techniques, 40. Brest, France

McRoy, C. P., Barsdate, R. J., Nebert, M. (1972). Phosphorus cycling in an eelgrass (Zostera marina L.) ecosystem. Limnol. Oceanogr. 17: 58-67

Pielou, E. C. (1969). An introduction to mathematical ecology, Wiley-Interscience, New York

Southward, A. J., Southward, E. C. (1978). Recolonization of rocky shores in Cornwall after use of toxic dispersants to clean up the Torrey Canyon spill. J. Fish. Res. Bd Can. 35: $682-706$

Wetzel, R. G., Penhale, P. A. (1979). Transport of carbon and excretion of dissolved organic carbon by leaves and roots/ rhizomes in seagrasses and their epiphytes. Aquat. Bot. 6: $149-158$ 